\title{
THE EFFECT OF POTENTIAL AND TDS TO CURRENT EFFICIENCY IN MINERAL WATER ELECTROLYSIS WITH SOLAR ENERGY SOURCE FOR PRODUCING ALKALINE AND ACIDIC WATER
}

\author{
Ekki Kurniawan ${ }^{1,2, \bowtie}$, Husein Bahti ${ }^{2}$, Anni Anggraeni ${ }^{2}$ and Iman Rahayu ${ }^{2}$ \\ ${ }^{1}$ School of Electrical Engineering, Telkom University, \\ Jl. Telekomunikasi No. 1, Bandung, Indonesia \\ ${ }^{2}$ Chemistry Department Post Graduate Program, Faculty of Mathematics and Natural Sciences, \\ Padjadjaran University, Jl. Raya Jatinangor, Indonesia \\ ${ }^{\square}$ Corresponding Author: ekkikurniawan@telkomuniversity.ac.id
}

\begin{abstract}
Alkaline and acid water produced by electrolysis are believed to have health benefits. Alkaline water containing hydrogen for drinking can be an antioxidant that captures free radicals which will increase the immune system, while acidic water serves as an external medicine, antiseptic, or disinfectant. This paper aims to discuss the effect of the potential and the total dissolved solids (TDS) on the electrolysis currents variables. The electrolysis device is made simple utilizing a portable mineral water ionizer of which energy is generated from the solar cells module in Indonesia. The cathode and anode regions were separated by an ion-exchange membrane, the volume of the electrolysis container, the electrode material, and its dimension, were made fixed. The statistical data analysis was performed using linear and multiple regressions showed that the currents electrolysis were strongly influenced by the potential and TDS variables, but the effect of the TDS was more dominant than the potential. The current efficiencies of acidic formation were not significantly affected by electrolysis potentials and TDS, while the current efficiencies of alkaline formation were significantly affected by electrolysis potentials and TDS.
\end{abstract}

Keywords: Electrolysis, Potential, TDS, Mineral Water, Alkaline, Acidic, Current Efficiency.

RASĀYAN J. Chem., Vol. 14, No.2, 2021

\section{INTRODUCTION}

Water is of major importance to living things. Humans, for instance, need water to carry out their lives. Water content in the human body accounts for approximately $50-70 \%$ of total mass, depending on age, sex, and fitness. Daily water requirements are determined from a fluid turnover balance. Recommended daily water intake for adult women and men are $2700 \mathrm{ml}$ and $3700 \mathrm{ml}$. However, stress and heavy physical exercise can significantly increase water requirements. Drinking water is necessary to maintain body hydration. Besides, individual irregularities also differentiate the need for water intake. ${ }^{1}$ Minerals content in the water is very important for the human body. The equilibrium of mineral ions normalizes the process of body metabolism, regulates acid-base stability, and some of the minerals are used to make tissueforming. The excess or lack of a mineral will have an impact on the human body. ${ }^{2}$ We normally drink water not only to reduce thirst, but also as daily food components, such as in soup, and as a mild stimulant, such as tea, coffee, ginger water, juice, and others. Drinks are also consumed because of their vitality content, such as ginger water or herbal drinks are used in cold weather for warming up. ${ }^{3}$ The level of human health and immunity is reduced along with times, increasing age, tension levels, business as well as various types of food and drinks consumed. Accordingly, various diseases have emerged, such as cancer, diabetes, stroke, inflammation, etc. Alkaline water containing hydrogen for drinking can be an antioxidant that captures free radicals which will increase the immune system, while acidic water serves as an external medicine, antiseptic, or disinfectant.

Alkaline electrolyzed water (AEW) is produced by electrolyzing water that generates hydroxide ions. Reduced alkaline water is expected to have a preventive effect on several kinds of diseases oxidative

Rasayan J. Chem., 14(2), 1011-1018(2021)

http://dx.doi.org/10.31788/ RJC.2021.1426235 
RASĀYAN J. Chem.

stress such as cancer and diabetes. Alkaline water consumption can also help to avoid osteoporosis, protect cells with its antioxidant effects, decrease stress levels, and increase immune response. ${ }^{4}$ Acidic water from the electrolysis of mineral water is also called as Super-Oxidized Water (SOW). SOW is produced by an oxidation part of the redox reaction in the electrolysis. SOW contains a mixture of oxidizing compounds, in the form of acids, especially $\mathrm{HOCl}$ with a $\mathrm{pH}$ of 5.0-6.5 and an ORP value of $>$ $950 \mathrm{mV}$. SOW can act as a novel antiseptic or disinfectant that is ready to kill microorganisms within minutes of exposure. ${ }^{5}$ To keep the $\mathrm{HOCl}$ solution stable, maximize antimicrobial activity, and minimize unwanted by-products, the $\mathrm{pH}$ must be maintained at 3.5 to $5 .{ }^{6}$

Hydrogen molecules generated on electrode surfaces and dissolved in tap water are called hydrogen reduced water (HRW). Molecules of hydrogen give several advantages for helping to overcome diseases due to their unique chemical and physical properties. Hydrogen molecules are hostile to oxidative, including neutralizing free radicals of $\bullet \mathrm{OH}$ and $\bullet \mathrm{ONOO}-.^{7}$ Moreover, hydrogen molecules can recover skin lacerations in some immune disorders with the elimination of Reactive Oxygen Species (ROS). ${ }^{8}$ Hydrogen inhalation is a part of COVID-19 patient's protocol by China's National Health Commission. HydroShot is a novel, comprising nitric-oxide-stimulating citrulline that has been filled with molecular hydrogen, its recommended use as a healthy drink, and can be clinically examined for treating COVID-19 patients. ${ }^{9}$

Asian countries are mostly located on the equator, such as Indonesia has abundant solar energy sources. In normal weather conditions, the sun illuminates the Indonesian hemisphere for 10-12 hours every day with the solar radiation intensity of $4.8-7.2 \mathrm{kWh} / \mathrm{m}^{2}{ }^{10,11}$ Data from the Indonesian Directorate General for Renewable Energy in 2019, the installed capacity of solar power in Indonesia has only reached 100 MW or $0.05 \%$ from an available potential of $207,898 \mathrm{GW}$. However, the utilization of solar energy has not been maximized.

Thus, more efforts have to be conducted, such as increasing the DC voltage of solar cells module (SCM) through a power electronic converter. One of the tools that employ DC voltage is a water electrolysis system, which produces hydrogen, alkaline, and acid water. Currently, equipment for producing hydrogen, alkaline, and acidic water has been available on the market. However, they have the disadvantages of being still relatively expensive and not yet affordable to the wider community. Fig.-1 shows an electrolysis system of mineral water using energy from the sun. Solar energy is absorbed by SCM then stored in the battery. The electrical potential can be increased by a converter to supply the mineral water electrolysis which will produce hydrogen, alkaline, and acidic water.

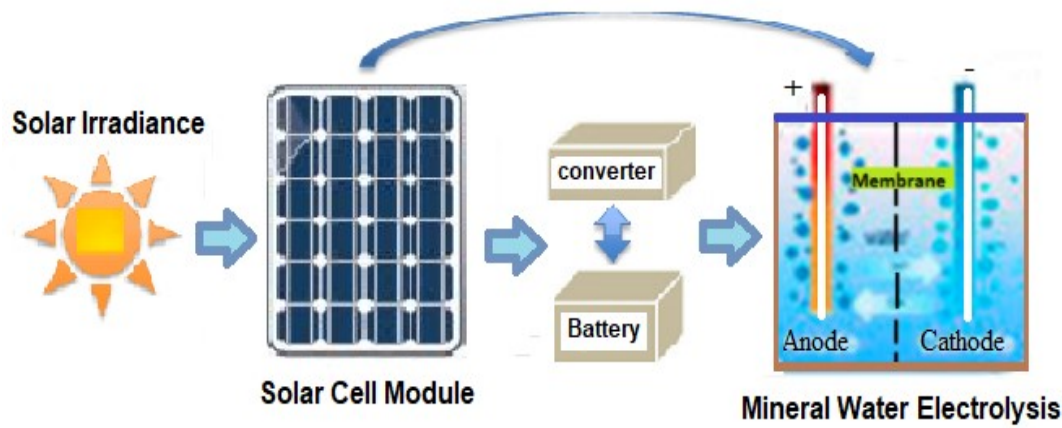

Fig.-1: Electrolysis System of Mineral Water with Energy from Solar Energy Source through SCM

\section{Designing and Implementing}

\section{EXPERIMENTAL}

The electrolysis tool is a simple electrolysis device that is easy to carry. It can separate mineral water ions and produce alkaline and acidic water in the presence of an electric field. A cathode side container made of teapot and anode side in the form of a small portable bottle, a hole is made in the bottle to be filled with a cotton membrane with an area of $8 \mathrm{~cm}^{2}$. The electrode materials were made from graphite carbon and stainless steel (SS), they were attached to the teapot cap with a length of $12 \mathrm{~cm}$, a diameter of $1 \mathrm{~mm}$, distance of $7 \mathrm{~cm}$, the electrolysis power supply comes from a source of solar energy, with different 
RASĀYAN J. Chem.

Vol. 14 | No. 2 |1011-1018| April - June | 2021

installation methods resulting in different voltages. The electrolysis power supply consisted of solar cell modules (SCM), batteries, inverters, and rectifiers. The measuring instrument consists of measuring cups, pH meters, TDS meters, and multimeters/AVO-meters. The SCM specifications showed a maximum power of $50 \mathrm{Wp}$, with maximum voltage and current 18 volts and 2.7 amperes, the number of cells of 36 (9x4), monocrystalline crystal types, and weight of one module of 3.3 kilograms. The batteries used were Lead-Acid, dry types, with a voltage of 12 volts and a capacity of 70Ah. The electrolysis instrumentation system is designed for portable use at a maximum fixed volume of 1.5 liters as shown in Fig-2.

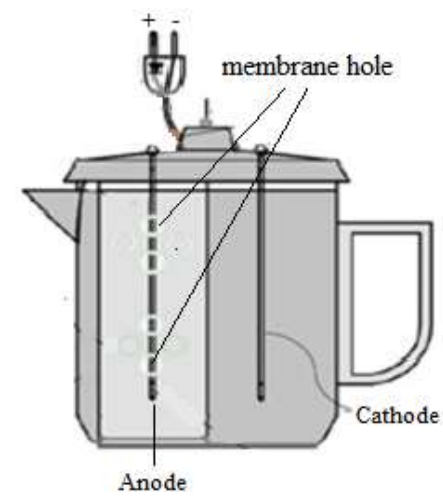

(a)
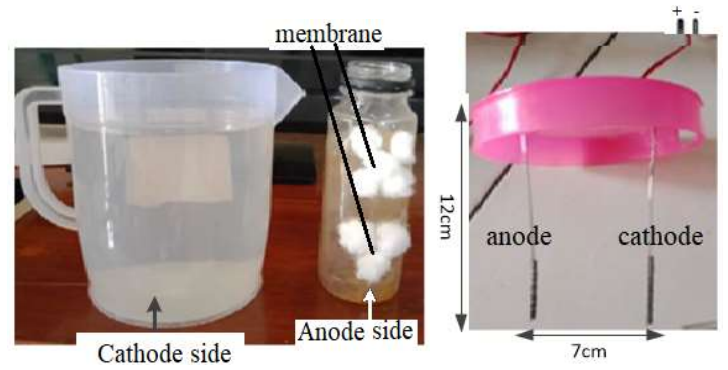

(b)
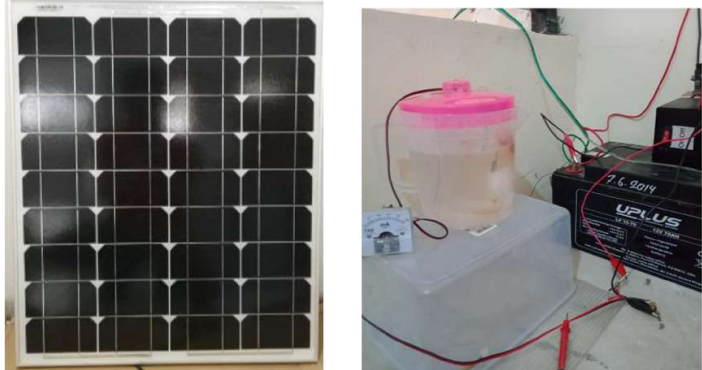

(c)

Fig.-2: (a) Electrolysis Container Design (b) The Implementation (c) The Measurement Process of Mineral Water Electrolysis with Energy through SCM

\section{Testing and Measurement}

Chemical materials used were mineral water, aqua DM (demineralization water), and a pinch of table salt. This water was obtained from drinking water companies, and bottled water sold in the market. The types of water studied was also measured based on TDS value as follows:

Type-1: Water tap from PAM Bandung City Company, which showed a TDS value of $124 \mathrm{ppm}$.

Type-2: Bottled mineral water which showed a TDS value of $150 \mathrm{ppm}$.

Type-3: Aqua DM added three times with table salt, so the TDS values increase from 0 to 163, 329, and $694 \mathrm{ppm}$.

The experiment was carried out in three ways to get some different voltages, i.e. directly using SCM (18.5, 19.3, and 19.7 volts), using the battery (10.4 and 10.7 volts), and using a converter (47.1 and 69.0 volts). The experiments were sorted by type of water-based on TDS value i.e. $124 \mathrm{ppm}$ three times, 150 ppm three times, 169,329, and $649 \mathrm{ppm}$. Each electrolysis experiment was carried out for one hour with a total water volume of $1400 \mathrm{ml}$, consisting of $1200 \mathrm{ml}$ on the cathode side and $200 \mathrm{ml}$ on the anode side.

\section{Calculation and Analysis}

Current Efficiency is formulated by equation $\mathrm{CE}=\mathrm{m} / \mathrm{M}, \mathrm{m}=$ moles taken from experimental results, calculated based on $\mathrm{pH}$ measurements. $\mathrm{M}=$ the number of electron moles calculated due to measured current (i.t / F). The steps to calculate the Current Efficiency (CE) of acids formation on the anode and bases on the cathode are as follows: The current electrolysis and time were measured (i and t), the amount of charge was calculated $(\mathrm{Q}=\mathrm{i} . \mathrm{t})$, then the number of moles were calculated by dividing by the faraday number $(\mathrm{F})$. The number of electron moles ratio can be seen from the reaction equation, i.e. additional moles of $\mathrm{H}_{3} \mathrm{O}^{+}$equal to additional moles of $\mathrm{OH}$ - and additional moles of electrons. From the increase or decrease in $\mathrm{pH}$, the additional number of $\mathrm{H}_{3} \mathrm{O}^{+}$and $\mathrm{OH}^{-}$moles were calculated. The ratio between 
RASĀYAN J. Chem.

Vol. 14 | No. 2 |1011-1018| April - June | 2021

additional moles of $\mathrm{H}_{3} \mathrm{O}^{+}$to additional moles of electrons showed a current efficiency of acid formation (CE-A) on the anode, meanwhile, the ratio between additional moles of $\mathrm{OH}^{-}$to additional moles of electrons showed a current efficiency of base/alkaline formation (CE-B) on the cathode side.

At the cathode side:

At the anode side:

$$
\begin{gathered}
4 \mathrm{H}_{2} \mathrm{O}_{(\mathrm{l})}+4 \mathrm{e}^{-} \rightarrow 2 \mathrm{H}_{2(\mathrm{~g})}+4 \mathrm{OH}^{-}{ }_{(\mathrm{aq})} \\
4 \mathrm{H}_{3} \mathrm{O}^{+}(\mathrm{aq})+4 \mathrm{e}^{-} \rightarrow 2 \mathrm{H}_{2(\mathrm{~g})}+4 \mathrm{H}_{2} \mathrm{O}_{(\mathrm{l})} \\
\hline 4 \mathrm{H}_{3} \mathrm{O}^{+}{ }_{(\mathrm{aq})}+8 \mathrm{e}-\rightarrow 4 \mathrm{H}_{2(\mathrm{~g})}+4 \mathrm{OH}^{-}(\mathrm{aq})
\end{gathered}
$$

$$
\begin{gathered}
4 \mathrm{OH}^{-}\left(\text {aq) } \rightarrow \mathrm{O}_{2(\mathrm{~g})}+2 \mathrm{H}_{2} \mathrm{O}_{(\mathrm{l})}+4 \mathrm{e}^{-}\right. \\
6 \mathrm{H}_{2} \mathrm{O}_{(\mathrm{l})} \rightarrow \mathrm{O}_{2(\mathrm{~g})}+4 \mathrm{H}_{3} \mathrm{O}^{+}(\mathrm{aq})+4 \mathrm{e}^{-} \\
4 \mathrm{H}_{2} \mathrm{O}_{(\mathrm{l})}+4 \mathrm{OH}^{-}(\mathrm{aq})
\end{gathered}
$$

On the cathode and anode side, there are eight moles of electrons which produce four moles $4 \mathrm{OH}^{-}$(aq) and four moles $4 \mathrm{H}_{3} \mathrm{O}^{+}$(aq) or in other words, the ratio of number electrons and hydroxide ions and hydronium ions is $2: 1 ; 1$, but not all $\mathrm{H}_{3} \mathrm{O}^{+}$(aq) ions bind to negative ions (such as $\mathrm{Cl}^{-}, \mathrm{NO}_{3}{ }^{-}$, and $\mathrm{SO}_{4}{ }^{2-}$ ) to form acidic solutions, some are drawn to the cathode. Likewise, not all of the $\mathrm{OH}^{-}($aq) ions bond the positive ions $\left(\mathrm{Na}^{2+}, \mathrm{K}^{+}, \mathrm{Ca}^{2+}\right.$, and $\left.\mathrm{Mg}^{2+}\right)$ to form the alkaline solution; some were attracted to the anode side. Therefore, it is necessary to calculate the current efficiency of the formation of acids and bases (alkaline).

An application data analysis software provided in Microsoft Excel ${ }^{12,13}$, especially in the regression was used to investigate the relationship among the current electrolysis (amps), the potential (volts), and the TDS (ppm). TDS is one of the important parameters of mineral or drinking water, ${ }^{14}$ TDS values are direct to mineral salt ions content that can form alkaline and acidic water. Current measurement has been utilized to calculate the CE-A and CE-B values in \%. Statistical analysis is used to determine, which independent variables have the most influence on electrolysis currents and their efficiency whether the potential or TDS. Some other variables that may have an influence such as volume of electrolysis container, area of the membrane, dimensions of the electrode are fixed, as the controlled variables. The independent variables consist of the source potential and the TDS. The dependent variables consist of current electrolysis, the CE-A and CE-B. The Summary output from regression analysis data as follows:

- Coefficient to find out the slope gradient in linear equation or the multiplier on the independent variable in the regression equation.

- P-value or Sign.F determines the significance of the effect simultaneously.

- Mult. $\mathrm{R}$ is used to determine the level of correlation between independent and dependent variables.

- $\mathrm{R} / \mathrm{Adj} . \mathrm{R}^{2}$ is the coefficient to determine the percentage of the influence of the independent variables and the remaining were influenced by other factors.

\section{RESULTS AND DISCUSSION}

Electrolysis measurement resulted from some mineral water can be seen in Table-1. Electrolysis of mineral water with TDS average of $218 \pm 57.9 \mathrm{ppm}$, and the potential average of $30.5 \pm 8,17$ volts in one hour time, found that the maximum, minimum, and the average of current electrolysis were $0.310,0,004$, 0.061 amperes. From the first six experiments, it can be seen that when the TDS values were constant, the increase in potential causes an increase in electrolysis current, and also when the values of potential were constant, the increase in TDS causes an increase in electrolysis current. The $\mathrm{pH}$ measurements were carried out on the cathode and anode sides which produced alkaline water and acid water. The maximum $\mathrm{pH}$ of the alkaline solution of 11.2 and the minimum $\mathrm{pH}$ of acid water might reach 3.0. The lowest and highest $\mathrm{pH}$ changes were 0.4 and 4.7 when the electrolysis currents are 0.004 and $0.310 \mathrm{amps}$. The values of the currents were proportional to the $\mathrm{pH}$ change, but not directly proportional to its efficiency, as seen in Fig-3. The average of CE-A and CE-B was calculated and give the value of $9.47 \pm 3.14 \%$ and $3.35 \pm$ $1.83 \%$. The value of CE-A was greater than the value of CE-B, almost three times, this is because the volume of the base $(1200 \mathrm{ml})$ is six times the volume of the acid $(200 \mathrm{ml})$.

Table- 2 shows the results of data analysis using regression at the $95 \%$ confidence level. Data analysis was carried out three times: In the first data analysis, current electrolysis in units ampere, I(A) as the 
RASĀYAN J. Chem.

Vol. 14 | No. 2 |1011-1018| April - June | 2021

dependent variable, the independent variable are power supply potential in units volt, $\operatorname{Pot}(\mathrm{V})$ and electrolyte TDS in units ppm. In the second and third analyses, the dependent variables are the efficiency of the CE-A and CE-B in units \%, meanwhile potential, TDS, and electrolysis current as of the independent variables.

Table-1: Measurement Data from Electrolysis Experiment and CE Calculation

\begin{tabular}{|c|c|c|c|c|c|c|c|}
\hline \multirow{2}{*}{$\begin{array}{c}\text { TDS } \\
\text { (ppm) }\end{array}$} & \multirow{2}{*}{$\begin{array}{l}\text { Potential } \\
\text { (volts) }\end{array}$} & \multirow{2}{*}{$\begin{array}{l}\text { Current } \\
\text { (A) }\end{array}$} & \multicolumn{3}{|c|}{$\mathrm{pH}$} & \multirow{2}{*}{$\begin{array}{c}\text { CE-A } \\
(\%)\end{array}$} & \multirow{2}{*}{$\begin{array}{c}\text { CE-B } \\
(\%)\end{array}$} \\
\hline & & & Initial & Acid & Base & & \\
\hline 124 & 10.7 & 0.004 & 6.7 & 5.9 & 7.1 & 0.284 & 0.061 \\
\hline 124 & 19.7 & 0.014 & 6.7 & 3.4 & 8.1 & 30.39 & 0.26 \\
\hline 124 & 69.0 & 0.044 & 6.7 & 3.2 & 8.6 & 5.674 & 0.20 \\
\hline 150 & 10.7 & 0.008 & 7 & 4 & 8.3 & 13.39 & 0.76 \\
\hline 150 & 18.5 & 0.016 & 7 & 3.8 & 8.7 & 3.92 & 0.61 \\
\hline 150 & 69.0 & 0.059 & 7 & 3 & 9.2 & 15.29 & 0.59 \\
\hline 163 & 10.4 & 0.028 & 6.5 & 3.6 & 9.8 & 9.78 & 7.38 \\
\hline 329 & 47.1 & 0.067 & 6.5 & 3.4 & 9.9 & 6.37 & 3.81 \\
\hline 649 & 19.3 & 0.310 & 6.5 & 4.3 & 11.2 & 0.17 & 16.44 \\
\hline
\end{tabular}
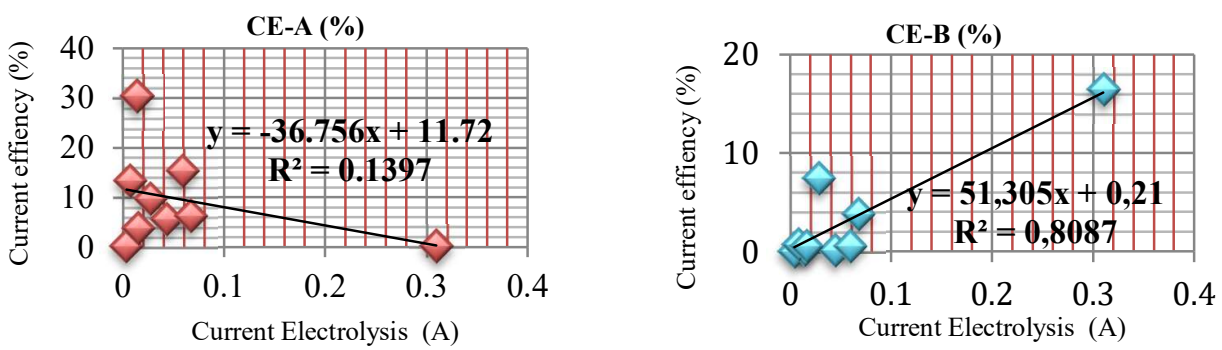

Fig.-3: Graph of Current Electrolysis to its Efficiencies CE-A and CE-B

Table-2: The Value of Regression Analysis Result at Level Confident of 95\%

\begin{tabular}{|c|c|c|c|c|c|c|c|c|}
\hline No & $\begin{array}{l}\text { Depend. } \\
\text { variable }\end{array}$ & $\begin{array}{c}\text { Independent } \\
\text { variable }\end{array}$ & Coefficient & p-value & Mult. R & $\mathrm{R} / \mathrm{Adj} . \mathrm{R}^{2}$ & Sign.F & $\begin{array}{c}\text { Std } \\
\text { Error }\end{array}$ \\
\hline \multirow[t]{2}{*}{$1^{\text {st }}$} & \multirow[t]{2}{*}{$\mathrm{I}(\mathrm{A})$} & $\operatorname{Pot}(V)$ & 0,00044 & 0.33 & \multirow{2}{*}{0.97} & \multirow{2}{*}{$0.93 / 0.91$} & \multirow{2}{*}{0.00031} & \multirow{2}{*}{28.8} \\
\hline & & TDS(ppm) & 0,00054 & 0.000098 & & & & \\
\hline \multirow[t]{6}{*}{$2^{\text {nd }}$} & CE-A (\%) & $\mathrm{I}(\mathrm{A})$ & -37 & 0.32 & 0.37 & $0.14 / 0.02$ & 0.32 & 9.36 \\
\hline & \multirow{2}{*}{ CE-A $(\%)$} & $\operatorname{Pot}(\mathrm{V})$ & 0.0001 & 0.99 & \multirow{2}{*}{0.41} & \multirow{2}{*}{$0.17 /-0.11$} & \multirow{2}{*}{0.57} & \multirow{2}{*}{9.93} \\
\hline & & TDS(ppm) & -0.022 & 0.31 & & & & \\
\hline & \multirow{3}{*}{ CE-A $(\%)$} & $\mathrm{I}(\mathrm{A})$ & 30.7 & 0.84 & \multirow{3}{*}{0.42} & \multirow{3}{*}{$0.17 /-0.31$} & \multirow{3}{*}{0.79} & \multirow{3}{*}{10.83} \\
\hline & & $\operatorname{Pot}(\mathrm{V})$ & -0.01 & 0.94 & & & & \\
\hline & & TDS(ppm) & -0.03 & 0.67 & & & & \\
\hline \multirow[t]{6}{*}{$3^{\text {rd }}$} & CE-B (\%) & $\mathrm{I}(\mathrm{A})$ & 51 & 0.00097 & 0.90 & $0.81 / 0.78$ & 0.00097 & 2.56 \\
\hline & \multirow{2}{*}{ CE-B (\%) } & $\operatorname{Pot}(V)$ & -0.0037 & 0.33 & \multirow{2}{*}{0.92} & \multirow{2}{*}{$0.85 / 0.80$} & \multirow{2}{*}{0.0032} & \multirow{2}{*}{2.42} \\
\hline & & TDS(ppm) & 0.0028 & 0.0013 & & & & \\
\hline & \multirow{3}{*}{$\begin{array}{c}\text { CE-B } \\
(\%)\end{array}$} & $\mathrm{I}(\mathrm{A})$ & 38.9 & 0.29 & \multirow{3}{*}{0.94} & \multirow{3}{*}{$0.88 / 0.81$} & \multirow{3}{*}{0.0088} & \multirow{3}{*}{2.35} \\
\hline & & $\operatorname{Pot}(\mathrm{V})$ & -0.05 & 0.20 & & & & \\
\hline & & TDS(ppm) & 0.007 & 0.71 & & & & \\
\hline
\end{tabular}

The regression equations that relate the effect of voltage and TDS on electrolytic currents and its efficiency in acid and alkaline formation are:

$\mathrm{I}(\mathrm{A})=0.00044 \mathrm{Pot}+0.00054 \mathrm{TDS}-0.0691$

CE-A $(\%)=0.0001$ Pot -0.022 TDS +14

$\mathrm{CE}-\mathrm{B}(\%)=-0.0037 \mathrm{Pot}+0.0028 \mathrm{TDS}-1.67$ 
RASĀYAN J. Chem.

Vol. 14 | No. 2 |1011-1018| April - June | 2021

CE-A (\%) $=30.7 \mathrm{I}-0.01$ Pot $-0.03 \mathrm{TDS}+16.5$

$\mathrm{CE}-\mathrm{B}(\%)=38.9 \mathrm{I}-0.05 \mathrm{Pot}+0.007 \mathrm{TDS}-1.02$

The first data analysis explains that, based on the value of the coefficient, the TDS variable (0.00054) provides a multiplier that is more dominant than the potential $(0.00044)$. Based on the p-value the TDS gives a value of $0.00095(<5 \%)$; meanwhile potential gives a p-value of $0.33(>5 \%)$, which means the TDS has a very significant effect, while potential has a less significant effect. However, both of them contributed to the effect with a significance value of $0.00031(<5 \%)$, from the correlation value and the combined determination of the two variables give a very strong correlation (0.97), with an adjacent coefficient of determination of 0.91 , this shows that $91 \%$ of the current is influenced by potential and TDS factors, while the remaining $9 \%$ was influenced by other factors, such as the electrolyte volume, distance, and dimensions of the electrodes, or the area of the membrane. Figure-4 shows the graph in three dimensions from the regression equation which can be used to predict the relationship between TDS and potential to current electrolysis.

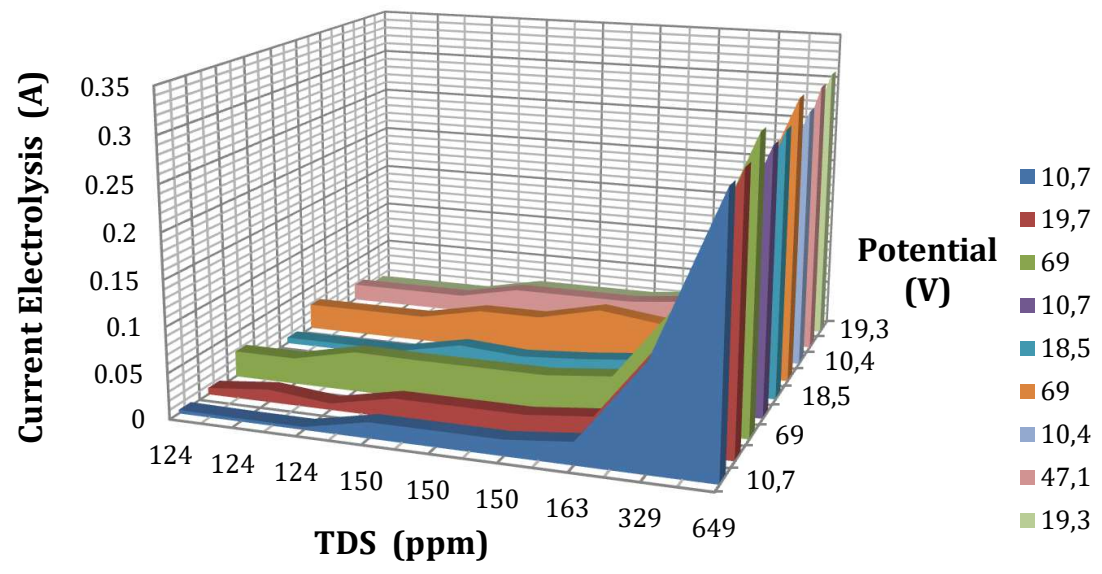

Fig.-4: Graph Relations between TDS and Potential to Current Electrolysis

The second data analysis explains the effects of the potential, TDS, and the current electrolysis on its CE$\mathrm{A}$, Based on the $\mathrm{p}$-value and its F significance, they give the values of $0.32 ; 0.99 ; 0.31$ (all $>5 \%$ ). and 0.32 ; $0.57 ; 0.79$ (all $>5 \%$ ). It means that the potential, TDS, and electrolysis current give less significance. The average correlation gives a value of 0.40 indicates there was an intermediate relationship (moderate) among all factors. The average determination coefficient of 0.16 , means that only $16 \%$ of CE-A was influenced by the potential, TDS, and the current electrolysis while the remaining is $84 \%$, influenced might be by other factors such as electrolyte volume, electrode dimensions, or membrane area. The third data analysis explains the effect of the potential, TDS, and current electrolysis on the CE-B. Based on the value of $F$ significance: $0.00097,0.0032$, and 0.0088 (all $<5 \%$ ). It means that the influence of current electrolysis, potential, and TDS was very significant. If seen from the average correlation value, it gives a very strong correlation (0.90), with a determination coefficient of 0.81 ; this shows that $81 \%$ of CE-B is affected by current while the remaining $19 \%$ is influenced by other factors. Figure- 5 shows the graph of the potential and TDS to CE-A and CE-B. The maximum value of CE-A based on the regression equation is $11.58 \%$ at $69 \mathrm{~V}$ potential and TDS $124 \mathrm{ppm}$. The maximum value of CE-B is $15.9 \%$ when the potential of 19.7 volts and TDS of $649 \mathrm{ppm}$.

\section{CONCLUSION}

Based on the results of the calculation, the average value of the current efficiency of the formation of acidic water is greater than the efficiency of the formation of alkaline water, both are relatively small lower than $10 \%$. This happened because not all of the hydronium ions that were decomposed are bound to the acid ions, also not all of the hydroxide ions that have broken down are bound to the alkaline ions. Some ions are attracted to the cathode and anode sides. Based on regression statistical data analysis, the 
RASĀYAN J. Chem.

Vol. 14 | No. 2 |1011-1018| April - June | 2021

TDS value and electrolysis potential have both significant effects on current and its efficiency, but the effect of TDS is more dominant. The efficiency of alkaline formation has a stronger correlation compared to acidic formation; one of the influencing factors was the volume of acidic water less than alkaline water.
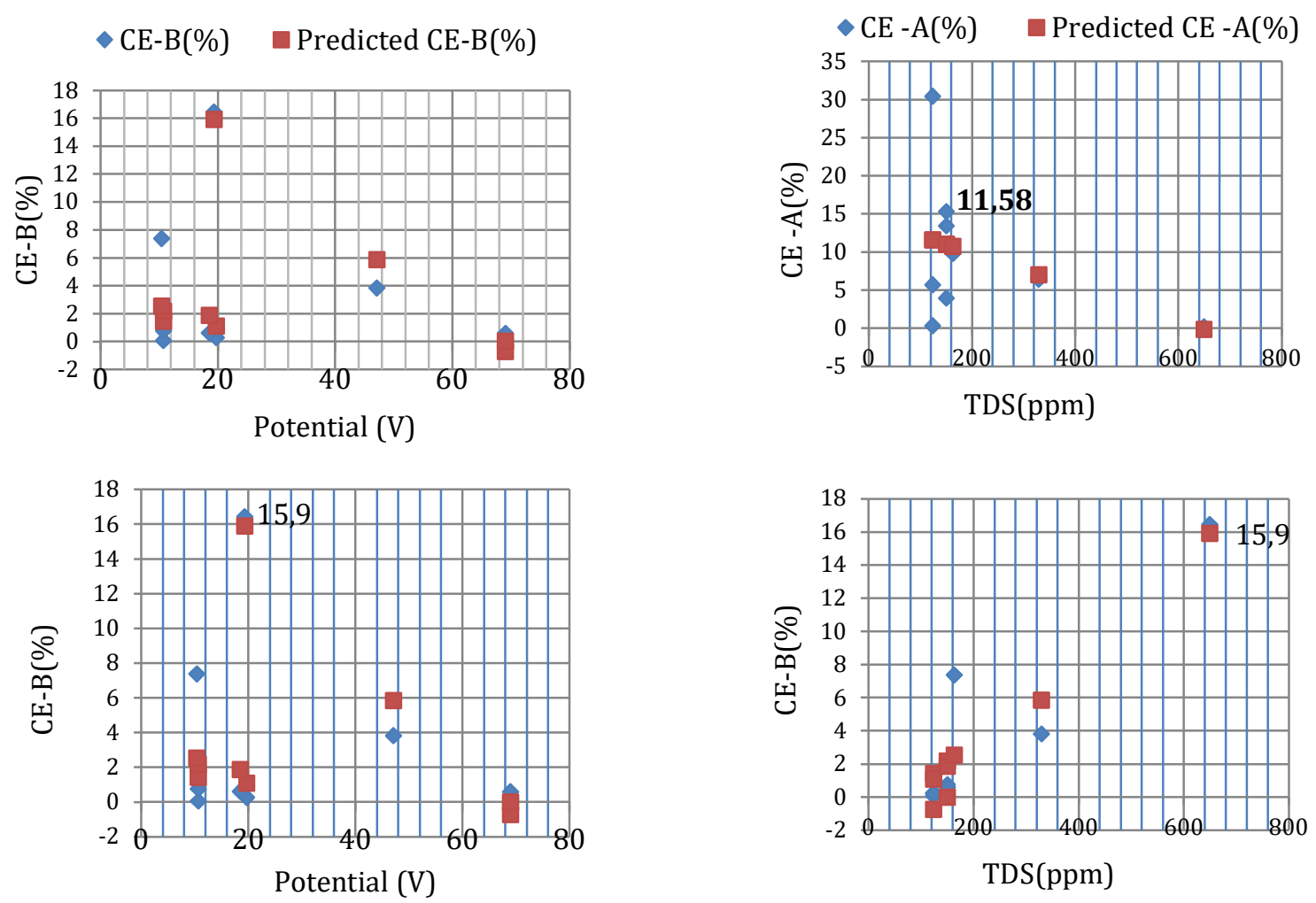

Fig.-5: Graph of Potential and TDS to Current Efficiencies CE-A and CE-B

\section{ACKNOWLEDGEMENT}

Thanks to the Indonesian Ministry of Higher Education, Research, and Technology for supporting this research. We would also like to deliver our gratitude to Prof. Tati Herlina, Chairman of the Postgraduate Program of Chemistry Department, Mathematics and Science Faculty, Padjadjaran University, and Dr. Bambang Setia Nugroho, Dean of Faculty of Electrical Engineering, Telkom University Bandung Indonesia.

\section{REFERENCES}

1. O. Stephanie, J. Beaumont, M. Toledo, A. Yudell, S. Carol, and C. W. Floris, Sports,7(7), 155(2019), DOI: 10.3390/sports7070155

2. G. Haro, I. Iksen, R. M. Rumanti, N. Marbun, R.P.Sari, and R.P.J. Gultom, Rasayan Journal of Chemistry, 11(1), 232(2018), DOI:10.7324/RJC.2018.1112011

3. B. M. Popkin, K. E. D'Anci, and I. H. Rosenberg, Nutrition Reviews, 68(8), 439(2010), DOI: $10.1111 / j .1753-4887.2010 .00304 . x$

4. S. Shirahata, H. Takeki, and T. Kiichiro, Trends in Food Science and Technology, 23(2), 124(2012), DOI: $10.1016 /$ j.tifs.2011.10.009

5. K.G. Munesh, P. Pradyot, B. Sujit, A. K. Paswan, D. K. Singh, and R.Tilak, Annals of Pathology and Laboratory Medicine, 04(1), A19(2017), DOI:10.21276/APALM.2017.982

6. Erinofiardi, P. Gokhale, A. Date, A. Akbarzadeh, A.F.Suryono, A. K. Mainil, and A. Nuramal, Energy Procedia, 110, 316(2017), DOI:10.1016/j.egypro.2017.03.146

7. S.Ohta, Methods in Enzymology, 555, 289(2015), DOI:10.1016/bs.mie.2014.11.038

8. M.Yang, Y. Dong, Q.He, P.Zhu, Q.Zhuang, J. Shen,X.Zhang, and M.Zhao,Oxidative Medicine and Cellular Longevity, 2020, DOI:10.1155/2020/8384742 


\section{RASĀYAN J. Chem.}

Vol. 14 | No. 2 |1011-1018| April - June | 2021

9. T.W. LeBaron, M.L. McCullough, and K.H. Ruppman Sr, Journal of Translational Science, 6, 1(2020), DOI:10.15761/JTS.1000380

10. C. Landa-Solis, D. González-Espinosa, B. Guzmán-Soriano, M. Snyder, G. Reyes-Terán, K. Torres, and A.A. Gutierrez, The Journal of Hospital Infection, 61(4),291(2005), DOI:10.1016/j.jhin.2005.04.021

11. A.M. Fathoni,N. A.Utama, and M. Kristianto,Procedia Environmental Sciences, 20, 89(2014),DOI:10.1016/j.proenv.2014.03.013

12. S. Shiyan, T. Hertiani, R. Martien, and A. K. Nugroho, Rasayan Journal of Chemistry, 12(3), 1098(2019), DOI: 10.31788/RJC.2019.1235276

13. H. P. C. A. Cane, N. Saidi, M. Mustanir, D. Darusman, R. Idroes, and M. Musman, Rasayan Journal of Chemistry, 13(4), 2215(2020), DOI:10.31788/ RJC.2020.1345818

14. M. Upadhyay, and M. K. Jindal, Rasayan Journal of Chemistry, 13(3),1777(2020), DOI:10.31788/ RJC.2020.1335853

[RJC-6235/2020] 